\title{
Building Of Spirit of Islamic Entrepreneurship On The Indonesia Young Generation
}

\author{
Pribanus Wantara \\ Economic and Business Faculty \\ University of Trunojoyo Madura \\ S. Anugrahini Irawati \\ Economic and Business Faculty \\ University of Trunojoyo Madura
}

\begin{abstract}
Since of economic crisis in Indonesia, people tried in various ways to fulfill their needs. Cessation work, limited job opportunities also contribute to increasing the number of unemployment in Indonesia. It encourages people to seek alternatives to improve the standard of an unbalanced economy. Majority Indonesian is Muslim. Hence, it becomes a task to be able to give birth to the entrepreneur Muslim reliable. This article talked about general basic principle of entrepreneurship viewed by history of Muhammad's life as a succeed entrepreneur. Mohammed before being known as prophet, has been recorded as an entrepreneur. Personal success is personal to identify, optimize potency, identity continuously with full confidence andstrong self confidence. So that, it is necessary to refresh the mindset of the basic concepts of business right through entrepreneurship characterized by reviewing the success of Muhammad as the best real entrepreneurship. Learning back of the concept is expected to arouse the public in carrying out efforts to correct and bring benediction Indonesian people, especially in the face of global competition. The results of this study indicate that the basic concept of entrepreneurship according to Muhammad's life history is built by Integrity, Loyalty, Professionalism and Spirituality.
\end{abstract}

Keywords: Entrepreneurship, History of Muhammad's Life, Globalization Era

\section{INTRODUCTION}

There is no nation that is prosperous and valued by other countries without being supported by economic progress. Economic progress will be achieved if there is an entrepreneurial spirit, which is strong from its citizens. China, South Korea and India are increasingly triumphant in raising their products as national flags on the global stage, because these three countries have an entrepreneurial spirit of their people, which are fully supported by their governments.

Developed countries generally have a greater number of entrepreneurs than developing countries, the United States, for example, has an entrepreneurship of 11.5 percent of the total population. Meanwhile 7.2 percent of Singaporeans are entrepreneurs so that the small country is progressing.

Indonesia, with all its natural resources, has only an entrepreneurship number of not more than 0.18 percent of the total population. Historically and consensus, a country must have at least 2 percent of the total population in order to advance. The Indonesian nation is increasingly racing against other nations that have already advanced. In fact, countries that have experienced economic crises such as Indonesia, which have led to the succession of active actors in the business world, are farther and farther. New corporations continue to emerge, 
controlled by young people with a strong business vision, a strong entrepreneurial spirit. Young business leaders continue to emerge, ready to bring their economies to a faster pace.

Since the economic, social and political crisis experienced by the Indonesian people has made the government and society worse off. Such conditions make us aware that various development policies and programs so far have not been able to completely solve the problem of the economic crisis so that the impacts include the fragility of joints, values and social norms. The causes of poverty can be caused by two factors (Tony, 2000). First, internal factors, namely: factors that exist in individuals, families or communities of the poor themselves, such as low levels of education and low levels of income. The two external factors are: influenced by Global policies such as social, political, legal and economic. Whereas from the point of view of the impact of poverty will have a very large impact if not addressed such as the decline in the quality of human resources, the emergence of inequality and social jealousy, disruption of social stability, increased crime rates and other social impacts.

\section{Entrepreneurship Concept}

\section{LITERATURE REVIEW}

The word entrepreneurship simply means entrepreneur that is buying at a fixed price even though the person does not know how much the item is sold, or the courage to take risks to open a business on various occasions without being overwhelmed by fear or anxiety even in uncertain conditions (Kasmir, 2007). Entrepreneurship, which means the properties of courage, virtue, exemplary, in taking risks based on one's own abilities.

Entrepreneurship literally means, courage and effort, or in other words the ability or courage someone has to see and assess business opportunities, gather the resources needed to take appropriate actions, and take advantage in order to achieve success.

Some notions of entrepreneurship, including:

a. According to Drucker (1973) entrepreneurship is a person who is able to read and create opportunities in every change.

b. Entrepreneurship as a process of applying creativity and innovation in solving problems and finding opportunities to improve life (business), (Zimmerer, 2002).

c. According to Wijandi (1988) entrepreneurship is a trait of courage, the virtue of exemplary in taking risks based on one's own abilities.

d. In Quick MBA (2010), the entrepreneur is defined as one who combines various input factors in an innovative manner to generate value to the customer with the hope that this value will exceed the cost of the input factors, thus generating superior returns that result in the creation of wealth.

e. Okpara (2000) defines entrepreneurship as the willingness and ability of an individual to seek out investment opportunities in an environment and be able to establish and run an enterprise successfully based on the identifiable opportunities.

Based on some of the meanings above, it can be concluded that the word entrepreneurial or entrepreneur means a fighter who is strong, tough, noble, courageous, and deserves to be an example in the field of business, in other words entrepreneurship is the process of creating something different in value using time and effort, bear financial, psychological and social risks that accompany it and receive monetary remuneration. 


\section{The Entrepreneurship Principle}

There are five important principles that must be held so that an entrepreneur can succeed in entrepreneurship, (Laode. 2006), namely:

\section{a. Build and maintain reputation (good name)}

Reputation is a fundamental thing in life especially in the business world because it is anonymousboth impossible to get business partners.

\section{b. Dare to step from the start}

Success cannot be achieved in a short time, success is not as easy as turning your palm. Success requires a process to form success itself. Like going up a ladder, step by step from the bottom and finally reaching the top.

\section{c. Concentration (Focus)}

If we have decided to enter a certain field, then we must focus and concentrate. This strength of focus is exactly what we must guard.

\section{d. Creative and innovative}

Creative, means being able to create something different and not just joining in. Not going into a place or field that has been entered by other people (not followers) except being able to provide more value that their distinguishes us from other players. An entrepreneur, it is impossible to exist and develop without the ability to create something new at all times. Creativity can come from anyone and from anything. Creative people are people who dare to take risks, there is success there is a risk, a small risk of the possibility of success is small and vice versa the big risk of success is great.

\section{e. Capital is not the main thing}

Real capital is only as a complement, almost everyone does not dare to start entrepreneurship on the grounds of capital constraints, they think to start a business there must be large capital.

Even as said an entrepreneur Chandra (2001) in his book Becoming a Successful Entrepreneur, to be a successful person is not needed money, only three things are needed, namely: Dare to be Optimistic with the Power of Others, Dare to Be Optimistic with Others, and Brave Optimistic with the Business of Others, so that the concept will deliver Chandra to successfully build Primagama Group tutoring; and became a giant tutoring that has branches throughout Indonesia.

\section{Entrepreneurship Character and Competence}

Entrepreneurship arises when an individual dares to develop new businesses and ideas. An important entrepreneur has a vision and mission in his business. This is a powerful force in planning, organizing, mobilizing, monitoring, personality, direction, coordination, reporting, efficiency (funds). It means that there is a synergy in competencies that directs business and characteristics.

Competencies need to be possessed by entrepreneurs like other professions, these competencies support them towards success. There are 10 competencies that must be possessed, (Dun and Bradstreet Business Credit Service, 1993), namely: knowing your business, knowing the basic business management, having the proper attitude, having adequate capital, having finances effectively, having time effectively,managing people, statisfying customer by providing high quality product, knowing hozu to compete,copying with regulation and paper work.Whereas, the characteristics are characteristics or behavior that are typical of entrepreneurs who distinguish them from others. 
The following are entrepreneurial characteristics according several experts:

According to the Bygrave characteristics (2003), it can be divided into 10, namely:

1) Dream, which is the vision and desire of the future to realize dreams.

2) Decisiviness, namely making decisions correctly, not slowly and postponed.

3) Doers, namely directly following up on the decisions that have been made.

4) Determination, which is carrying out its activities with full attention, responsibility, and does not want to give up.

5) Dedication, which is dedicated to the business, is willing to sacrifice.

6) Devotion, which is tireless, all attention is only devoted only to the business.

7) Details, must pay attention to critical factors in detail to the smallest thing.

8) Destiny, which is responsible for the fate and goals to be achieved.

9) Dollars, which does not prioritize achieving wealth. His motivation is not just money, but success.

10) Distribute, which is able to distribute or share ownership of the business with others.

\section{The Challenges of the young Entrepreneurs (students) in the Global Era}

An entrepreneur is a risk taker, both financial risk and mental risk. The current of globalization and modernization in all aspects of life also influences the world of entrepreneurs, both from the management of processing resources to the infrastructure used. If in the past, the method used was very simple, now the traditional method has been replaced by a variety of new and up-to-date methods, such as online businesses that do not recognize space and time limits. Globalization in the world of entrepreneurship also encourages the growth of young generations who are creative and innovative, resilient, highly committed and have a good personality as one of the capital to partner with other people. Students are no longer fixated on the dreams of becoming civil servants later, but they have been able to dream of becoming a successful entrepreneur in their own way. The global era also requires the growth of young entrepreneurs who are not only oriented towards capital infusion and maximum profit, but also guarding norms, social values, and participation in realizing the prosperity of society.

\section{Character and Principles of Entrepreneurship Muhammad SAW}

Since Muhammad SAW was 17 years old, he has had business activities so he encouraged him to have entrepreneurial character. His figure was very modest, but has soul as strong as steel. If we have time to visit Mecca, we will see the terrain of business being run that Muhammad SAW that was unusually heavy for our current size. It's very different from most business executives now who can board airplanes by sitting in comfortable business class. Muhammad SAW a number of times on a trade tour with terrain that was very dangerous and heavy. In this case we can analyze how great the determination of a business like Muhammad.

A true entrepreneur must indeed have a superior character. Winarto (2002) in his book First Step to An Entrepreneurs wrote the five characteristics of leading entrepreneurs as follows:

a. Dare to take risks. That is, dare to start something completely uncertain and risky. However, the risk has been carefully calculated

b. Likes a challenge. That is, everything is seen as a challenge, not a problem. Changes that occur actually raise the spirit of conquering.

c. Have high durability. That is, an entrepreneur must be resourceful (not tricks) and not easily discouraged

d. Got a far ahead vision. That is, everything that is done has a long-term goal even though it starts with a very small step.

e. Always trying to give the best. That is, an entrepreneur will direct all of his potential, including recruiting competent people to partner. 
Five superior characters if we attach it to the person of Muhammad, it is very appropriate for students. As an entrepreneur, Muhammad had forged himself to have excellent characters. In fact, he risked a distant trade journey since the age of 12 years, Muhammad also took the risk of greater responsibility by accepting a recruitment offer from Khadija for this, through his uncle, Abu Talib, the Holy Prophet negotiated wages until he received wages of four camels. Muhammad was also a visionary. He has a strategy in marketing by recognizing the background of the regions and the markets he will visit. Muhammad also built strategic cooperation with local traders to be able to expand his network (network marketing).

\section{DISCUSSION}

If we analyze the relevance of understanding, character and principles of an entrepreneur with the figure of Muhammad SAW, it is very appropriate and very close. In many ways, principles and models like this are often ignored so it is not surprising that many entrepreneurs fail in their businesses because they do not have personality integrity. Character building as a condition for the emergence of a good reputation is the main thing that becomes the foundation. Many people forget the positive character of doing business so that what appears is a negative character. Negative characters also have the attraction of attracting negative things, such as doubts, distrust, complaints and so on.

Muhammad SAW decided his career / profession as a trader since the age of 17 because he wanted to ease the burden on his uncle's family. He concentrated on selling clothes and other necessities purchased in the market, then reselling them. From this experience, Muhammad SAW has skills and knowledge about products and their quality. He provided added value with the breakthrough practice of selling so that he led him to become a professional trader.

Prophet Muhammad's business trip for years provided wisdom about how the business management elements of Rosulullah SAW. Even in the goat herding activities carried out by the Prophet there are noble values contained, namely: spiritual education, practice feeling compassion for the weak, and the ability to control heavy and large jobs. Antonio (2007) revealed the lessons learned from activities to herd goats on the elements of management are as follows:

1. Path finding. Looking for fertile pastures,

2. Directing. Looking for fertile pastures,

3. Controlling (watching) goats. In order not to get lost or separate from the group,

4. Protecting goats from predatory animals and thieves,

5. Reflecting (contemplation). Unitenature, humans and God

According to Trim (2009) the credibility and capabilities of the Prophet Muhammad are found in his four superior characters, namely FAST (Fathonah, Amanah, Siddiq and Tabligh), plus a factor, namely Istiqomah.

The nature of Fathonah (intelligent) in the Prophet Muhammad SAW was written by Sidik (2004), a Malaysian writer mentioned that Rosulullah was a genius with evidence of expertise as 1) political expert; 2) role strategists; 3) diplomacy experts; 4) expert relations between people; 5) strategists; 6) statesmen; 7) decision makers; 8) expert on institutionalization; 9) HR development experts; 10) community development experts; 11) family planning experts; 12) da'wah experts.

The nature of Amanah (commitment) is reflected in the attitude of the Prophet who always uses contracts, agreements or business agreements with a system of mutual agreement. Someone is considered negligent if he does not implement things that have been agreed upon. 
Rosulullah SAW said: "Allah Azzawajalla said:" I am a third party from both parties who are united as long as one of them does not betray his friend. If one of them betrays his friend, I am separated from both of them. "(Abu Dawud).

The nature of Siddiq (true and honest) can be reflected in some attitudes of the Prophet. First, Rosulullah is kind and honest with the company or shareholders. Evidently, after helping his uncle's business, Rosulullah was able to manage Khadijah's business well. Second, Rosulullah is kind and honest with employees. Prophet Muhammad once advised to pay the wages of an employee before his sweat dried. This shows that the company should not delay the right of an employee if the company is not having difficulty paying the salary.

Nature of Tabligh (Communicative).The nature of the Prophet to always be tabligh in line with the word of Allah SWT in QS. An-Nisa verse 9, namely: "........ therefore, let them fear Allah SWT and let them say the right words". The last is Istiqomah's nature (consistent determination). The Prophet is always istiqomah in carrying out Islamic business values (FAST) to be able to maintain business trust from others.

Loyalty is a supporting trait that strengthens the trust of many people. Loyalty is related to loyalty and long-term commitment. Muhammad SAW showed high loyalty to his uncle, Abu Talib. When the recruitment offer from Khadijahra arrived, Muhammad SAW handed over a decision to his uncle, Abu Talib. In terms of trade, Muhammad always practiced a soul that was loyal to his customers with the best service to anyone so that in contrast, his customers were also loyal to him. As a business manager, he was very concerned with moral issues so he was the main character who later gave birth to the concept of spiritual marketing. Spirituality awakened more strongly when Muhammad SAW married Khadijahra, Muhammad SAW spent more time competing as mentioned in history often alone in GuaHira. Rasulullah saw with his long-term vision of making ethics and business law; prevent a Muslim from doing wrong in his business activities.

\section{CONCLUSION}

Entrepreneurship is the nature of courage, virtue in exemplary in creating something different in value by using the effort and time required, carrying financial, psychological and social risks that accompany it and receiving monetary remuneration.Meanwhile the basic concept of entrepreneurship in the life of Muhammad SAW was built on integrity, loyalty, professionalism and spirituality. Students as young entrepreneurs are brave heroes, tough, noble, brave, and deserve to be an example in the field of business in creating something different in value by using the effort and time needed, carrying financial, psychological and social risks that accompany and receive monetary remuneration.

\section{References}

Alma, Buchari,. (2007). Kewirausahaan. Edisi Revisi. Jakarta: Alfabeta.

Antonio, Syafi'i., (2007). Muhammad SAW: The Super Leader Super Manager. Jakarta: Pro LM.

Bygrave, W. D., (2003).The Portable MBA Entrepeneurship. Jakarta: Binarupa Aksara.

Chandra, Purdi E., (2001). Menjadi Entrepreneur Sukses, Jakarta: PT Grasindo.

Dun and Bradstreet Business Credit Service., (1993). Strategy Plan and Business Plan. New York: Prentice Hall, Inc.

Drucker. P.F (1973). Management: Task, Responsibilities, Practicers, New York: Harper \& Row.

Kasmir. (2007). Kewirausahaan. Jakarta: PT. Raja Grafindo Perkasa. 
Laode Kamaluddin. (2006). Langkah-langkah Bagaimana Rasulullah SAW Membangun Kerajaan Bisnis, Republik, Jakarta, Cetakan ke-1.

Masykur Wiratno. (1994). Kewirausahaan. Jakarta: Gunadarma.

Okpara, I. O., (2000). Entrepreurship; Precious Printers and Publishers, Enugu.

Quick MBA., 2010. “Entrepreneurship: Definition”. Quick MBA.com. http://QuickMBA.com/ entre/Retrieved, 8th August, 2010.

Richard. (1937). Outliness of Company. Denverma.

Sidik, Roziah. (2004). Genius Muhammad bin Abdullah (Mengungkap Kepakaran Nabi dalam Pelbagai Dimensi Hidup). Selangor: PTS. Islamika.

Soedarsono W. (2002). Pengantar Kewirausahaan. Buku I Jurusan Teknologi Industri. IPB Bogor.

Suryana. (2001). Kewirausahaan. Jakarta: Salemba Empat.

Tony Prasetianto, A., (2000). Rambu-Rambu Yang Diabaikan. Jakarta: PT. Kompas Media Nusantara.

Trim, Bambang. (2009). Briliant Enterpreneur Muhammad SAW. Bandung: Salamadani.

Winardi. (2003). Entrepreneur and Entrepreneurship.Jakarta: Kencana Media Group.

Zimmerer, Thomas. (2002). Essentials of Entrepreneurship and Small Bussines Management, $3^{\text {rd }}$ Edition. Prentice Hall. Upper Sadleriver.

Winarto, Paulus. (2002). First Step to An Entrepreneurs. Jakarta: Elex Media Komputindo.

Wijandi, Soedarsono. (1988). Pengantar Kewirausahaan. Bandung: Sinar Baru. 